\title{
Greywater treatment in airports using anaerobic filter followed by UV disinfection: an efficient and low cost alternative
}

\author{
Eduardo de Aguiar do Couto*, Maria Lúcia Calijuri, Paula Peixoto Assemany, \\ Aníbal da Fonseca Santiago, Lucas Sampaio Lopes \\ Universidade Federal de Viçosa (Federal University of Viçosa), Department of Civil Engineering, Environmental Research Group, P. H. Rolfs, s/n, Campus \\ Viçosa-MG, 36570-000, Brazil
}

\section{A R T I C L E I N F O}

\section{Article history:}

Received 7 February 2014

Received in revised form

16 July 2014

Accepted 24 July 2014

Available online $\mathrm{xxx}$

\section{Keywords:}

Greywater

Airport environments

Water reuse

Rational use

\begin{abstract}
A B S T R A C T
Greywater reuse is one of the main alternatives for reducing potable water consumption in households, industries and commercial buildings. Airport complexes need large amounts of water to maintain their operation routine, and replacing potable water with greywater may represent significant savings of financial and environmental resources. The objectives of this study were to discuss aspects related to greywater reuse in airports of different regions, as well as to present a case study of an airport in Brazil. Greywater treatment and reuse are quite common worldwide, although not many airports have already implemented such practice. Even though several sophisticated technologies have been widely used in some airports, treating source-separated effluent requires simple techniques and facilitates reuse. The case study evaluated a system consisting of an anaerobic filter followed by ultraviolet disinfection. The results were satisfactory according to less strict reuse standards and an economic analysis showed that in five years the cost of the investment will be returned. Due to its simple operation, the system is mostly indicated for small and mid-size airports, or for decentralized treatment in large airports. Greywater reuse must increasingly become part of a set of integrated actions toward the rational use of water, since this type of effluent represents an alternative source for non-potable uses, with extensive applicability in airports.
\end{abstract}

(C) 2014 Elsevier Ltd. All rights reserved.

\section{Introduction}

The increasing pressure on water resources in order to satisfy the demands of the society brings the supply system to its limits. The conflicting uses also contribute significantly to raise concerns over water availability. In this scenario, water conservation gains significant importance since it involves its controlled and efficient use, as well as effluent reuse measures.

Greywater is defined as the wastewater from lavatories, showers, bathtubs, kitchen sinks and washing machines (Liu et al., 2010; Hernández-Leal et al., 2011; Couto et al., 2013), and is internationally recognized as an alternative water source for nonpotable uses (Ghaitidak and Yadav, 2013). Gilboa and Friedler (2008) state that greywater reuse is currently receiving increasing attention as an alternative to reduce potable water consumption

\footnotetext{
* Corresponding author. Tel.: +55 31 38993098; fax: +55 3138993093 .

E-mail addresses: eduardo.acouto@hotmail.com (E.A. Couto), calijuri@gmail.com (M.L. Calijuri), paula_assemany@hotmail.com (P.P. Assemany), anibalsantiago@ gmail.com (A.F. Santiago), lucasctu@gmail.com (L.S. Lopes).
}

due to its lower levels of pollutants compared to domestic sewage. In addition, according to Li et al. (2009), greywater represents a substantial fraction (50-80\%) of total wastewater produced in a household.

Airport environments need large amounts of water to maintain their infrastructure and operation routine (Moreira Neto et al., 2012a). However, great part of this volume is destined to nonpotable activities such as landscape irrigation, toilet flushing, washing of vehicles and paved areas, fire control testing, among others. Within this context, airports are potential environments for the implementation of processes and technologies aimed at the rational water use such as greywater reuse.

The main objectives of this paper were to present some aspects related to greywater reuse in airports, discuss the existing initiatives in different regions, and to present a case study of an airport in Brazil. This study examined the applicability of an anaerobic filter followed by UV disinfection for greywater treatment in airports, through an evaluation of the wastewater treatment efficiency and an economic analysis of the investment required to adopt such practice. 


\section{Greywater reuse}

\subsection{Conceptual aspects}

Greywater is related to the concept of source-separated effluent, which can facilitate treatment and reuse. Such separation is often considered an option for rural areas (Nelson and Murray, 2008). Larsen et al. (2009), however, state that this can be a sustainable alternative to end-of-pipe systems, inclusively in urban areas and industrialized countries.

Hernández-Leal et al. (2010) discuss the concept of decentralized sanitation and reuse, which proposes the separation of domestic sewage into blackwater (toilet effluent) and greywater, in order to provide a more specific treatment for each type of effluent and allow the use of resources that would be discarded. Thus, greywater has an aggregate value and should not be considered waste.

Friedler and Gllboa (2010) state that greywater reuse is attractive to local systems through the installation of treatment units in households, commercial buildings, industries and other establishments, so that the treated effluent can be used in activities at the very place where it is produced. Muthukumaran et al. (2011) state that greywater use in toilet flushing and landscape irrigation can reduce water consumption in at least $50 \%$.

Establishing norms and regulations regarding greywater quality is extremely important to minimize risks to users. The coherent definition of criteria is necessary to avoid setting too high limits and the unnecessary requirement of very sophisticated treatment technologies, which make reuse a lot more difficult and even unfeasible. Worldwide, there are only a few norms and regulations specific for greywater reuse; therefore, those defined for effluent reuse are usually applied. Table 1 shows the reuse norms and regulations established for different activities.

The values in Table 1 show the significant variation of standards among the activities and also from one region to another (each reference refers to a different location). This can be explained by the level of exposure to the contaminant that each activity offers to the user. As for the distinction among the locations, it reflects the different demands of each region, as well as their social and cultural aspects (Li et al., 2009). Indeed, the greywater characteristics are highly variable as influenced by factors such as lifestyle, social and cultural behavior of the residents, and water availability (Ghaitidak and Yadav, 2013).

From all regulations presented in Table 1, both the NSW (2002) and Environmental Agency (2011) are specific for greywater. The importance of establishing limits for turbidity and suspended solids is related to the possibility of pipe obstruction, acceptance by the users, interference in the disinfection process and the relation of such variables with the presence of protozoan cysts and oocysts. As for BOD, the importance of establishing maximum concentrations is related to the need to avoid the growth of microorganisms in the treated effluent (Winward et al., 2008). In the same manner, establishing values for residual chlorine is essential to avoid the proliferation of microorganisms in distribution pipe or storage reservoirs. WHO (2006) is the only reference that does not mention limit values for such variable. On the other hand, the same guide presents values for helminth eggs, which is not considered in the other norms.

Table 1

Norms and regulations for effluent reuse.

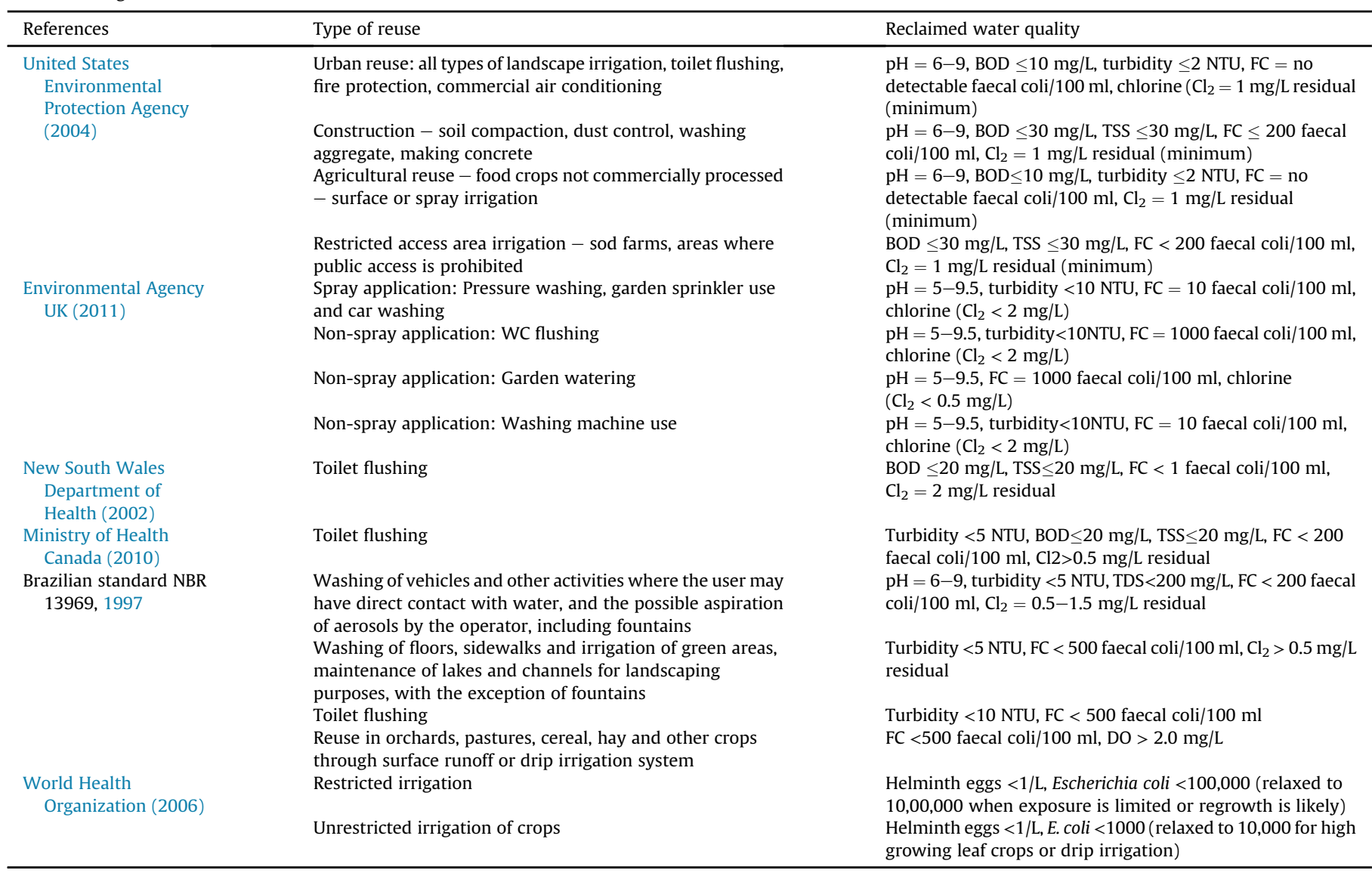

BOD: Biochemical oxygen demand; COD: Chemical oxygen demand; NTU: Turbidity units. 
Public and private organizations worldwide have recognized the importance of greywater as an alternative source for activities that do not require potable water, which has contributed to increase its reuse. In Australia, a sanitation policy encourages the implantation of greywater treatment systems for use in residential and commercial buildings. The program aims to increase in $70 \%$ the number of systems until 2015 (Pinto et al., 2010). In Barcelona, Spain, greywater reuse systems have been installed in new buildings. The main trigger of such trend was the approval of a local law that aims at water saving and the use of alternative sources to meet the growing demand. The program establishes that the users must take responsibilities for the water resources management, and the installation of greywater treatment systems for reuse purposes has become a basic premise for residential buildings (Domènech and Saurí, 2010). In India, in the state of Madhya Pradesh, greywater treatment systems consisting of settling tanks, filtration and chlorination were installed in 200 schools (Godfrey et al., 2009). Such effluent is used for toilet flushing, cleaning and landscape irrigation.

\subsection{Greywater treatment technologies}

The technologies applied for greywater treatment include physical, chemical and biological processes. The most common physical processes are sand filters and membrane filtration, usually followed by disinfection. March et al. (2004) assessed the use of greywater for toilet flushing in a hotel in Mallorca, Spain, after treatment which consisted of settling tanks, filtration (nylon screen filter) and disinfection using sodium hypochlorite. Variables such as chemical oxygen demand (COD), turbidity and suspended solids were reduced from $171 \mathrm{mg} \mathrm{L}^{-1}, 20 \mathrm{uT}$ and $44 \mathrm{mg} \mathrm{L}^{-1}$ to $78 \mathrm{mg} \mathrm{L}^{-1}$, $16.5 \mathrm{uT}$ and $18.6 \mathrm{mg} \mathrm{L}^{-1}$, respectively. According to the authors, the effluent characteristics showed good acceptance by the hotel guests.

According to Li et al. (2009), the main chemical treatment techniques applied to greywater are coagulation, ion exchange and activated carbon. Pidou et al. (2008) carried out a study that used coagulation and a magnetic ion-exchange resin. In optimal conditions, when coagulation was performed using aluminum salts, the COD, BOD and turbidity concentrations reduced from $791 \mathrm{mg} \mathrm{L}^{-1}$, $205 \mathrm{mg} \mathrm{L}^{-1}$ and $46.6 \mathrm{uT}$ to $247 \mathrm{mg} \mathrm{L}^{-1}, 27 \mathrm{mg} \mathrm{L}^{-1}$ and $3.01 \mathrm{uT}$, respectively. The use of iron salts provided similar results. According to the authors, the chemical treatment process can have a significant role when less restrictive standards are required, even as an alternative to biological treatment.

Several biological systems have been studied for the treatment of greywater, among which are the UASB reactor (Elmitwalli and Otterpohl, 2007), constructed wetlands (Li et al., 2003; Gross et al., 2007) and membrane bioreactor (Lesjean and Gnirss, 2006). Li et al. (2009) state that the aerobic processes are efficient in the removal of biodegradable matter, and consequently, avoid problems such as the growth of pathogens and unpleasant odors, which enables effluent storage for longer periods. Hernández-Leal et al. (2011), on the other hand, state that anaerobic systems are an interesting alternative due to the reduced cost and the possibility of energy use. The same authors reinforce the applicability of anaerobic systems for greywater treatment due to the fact that the reduced nutrient concentrations could limit the efficiency of aerobic systems.

\subsection{Greywater in airports: a global overview}

Great airports consume water in the same proportion as small and mid-size cities (Couto et al., 2013). The Hartsfield-Jackson International Airport, in Atlanta, transported 89.3 million passengers in 2010 , and consumed the equivalent to a city of 13,000 people (DOA, 2011). In the same year, the London-Heathrow Airport transported over 66 million passengers and presented consumption equal to that of a city of 25,400 people (LHR, 2010); the Charles de Gaulle-Airport in Paris presented consumption equivalent to that of a city with 31,400 people and transported 58.2 million passengers (ADP, 2010).

Passenger traffic worldwide has been increasing and is expected to continue to increase at an average rate of 5.3\% until 2029. In addition to the number of passengers, the cargo transportation will also increase, in the same period, around 5.9\% (Boeing Management Company, 2010). In many cases, such increase in airport activities may result in negative environmental impacts, which justifies the need of airports to continuously adjust to new policies and sustainable practices (Asinjo, 2011).

Greywater reuse in airports is not yet very widespread, although it has become part of the plans of action of some large airports worldwide. In Narita, Japan, greywater from kitchen sinks are directed to a treatment station consisted of a catalytic oxidation tank, ultrafiltration, filtration using activated carbon and disinfection, and then used for toilet flushing in the passenger's terminal (NIAC, 2011).

In the airport of Fiumicino, Rome, the kitchen sink effluent from catering companies is collected and, after physical separation of the fat fraction, treated with the domestic sewage in activated sludge units. The treated effluent is used for landscape irrigation, toilet flushing air cooling systems and reserve for fire control (ADR, 2009).

In the Hong Kong Airport, greywater from restaurants, aircraft catering, cleaning and bathroom sinks are collected and used for the irrigation of green areas. In 2011, an investment of more than U\$ $4,385,000.00$ was made for the expansion of the greywater treatment station. In addition to improving the quality of the effluent through the implantation of an aerobic process using a membrane biological reactor, the treatment capacity of the station increased from 1500 to $6000 \mathrm{~m}^{3}$ day $^{-1}$ (HKIA, 2011).

The Dubai Airport, in the United Arab Emirates, uses greywater to wash vehicles of the engineering companies. After reuse, they are directed to an effluent treatment station with a capacity to treat $80 \mathrm{~m}^{3}$ of effluent every day (DCA, 2004).

Several airports mention greywater reuse in their environmental management plans, although most of them have not yet implemented such practice. As an example, the Airport of Atlanta expects to use greywater in toilets until 2020 (DOA, 2011). In the airport of Hilton, Manchester, England, greywater reuse and rainwater use systems for non-potable uses are expected to be implemented by 2015, with the objectives to reduce consumption and save potable water only for drinking purposes and emergencies (MAG, 2007).

Assessing variables that interfere in water consumption in airport environments is extremely important given that water savings must be attained through integrated actions upon supply and demand. Since airports have distinct characteristics, different actions can be considered suitable for each situation. The supply management can be carried out considering other sources such as rainwater or even sanitary effluent, in addition to greywater reuse. As for the demand management, consumption can be controlled and reduced through education campaigns, substitution of obsolete by water saving sanitary fixtures and the reduction of leaks.

Carvalho et al. (2013) presented a review on the main sustainable practices related to water resources in airports and state that the high water consumption and effluent production in such environments may facilitate the implementation of greywater reuse in activities that do not require potable water. The authors also emphasize that the airports which have already implemented such 
practices serve as example to confirm their technical and economic feasibility, as well as the environmental benefits from water saving.

\section{Material and methods}

\subsection{Study area}

The study was carried out in the Tancredo Neves International Airport (TNIA), in the municipality of Confins, which is $35 \mathrm{~km}$ north of Belo Horizonte, the capital of Minas Gerais State, Brazil. The airport is located between $19^{\circ} 39^{\prime}$ and $19^{\circ} 37^{\prime} \mathrm{S}$ and $43^{\circ} 59^{\prime}$ and $43^{\circ} 57^{\prime} \mathrm{W}$. The TNIA has a total area of $15 \mathrm{~km}^{2}$ and the capacity to transport 10 million passengers every year (INFRAERO, personal communication).

In 2011, the airport transported 9,534,986 passengers and consumed $259,470 \mathrm{~m}^{3}$ of water, which is $31 \%$ higher than the volume consumed in 2010. This airport is currently being renovated for the expansion of the passengers' terminal and the construction of a remote terminal to increase its capacity to 15.5 million passengers a year (INFRAERO, 2013).

The airport is supplied by underground wells installed in the vicinity of the airport, which is relevant since the airport is situated in a karstic region, an extremely vulnerable environment, which already suffers with the negative impacts of anthropic actions (Calijuri et al., 2012). Thus, reducing water consumption and consequently decreasing the amount of water taken from the wells can provide not only financial gains but also invaluable environmental benefits.

\subsection{Greywater treatment unit}

The greywater treatment unit (GTU) was constructed in the maintenance sector of the Brazilian Airport Infrastructure Enterprise - INFRAERO, located in the TNIA.

The effluent was collected from the locker room used by the employees responsible for maintenance services. Greywater consisted of the effluent from bathroom sinks, showers, and from cleaning the locker room. In addition, kitchen sink effluent was added in the same proportion to which this effluent is produced in the building where the catering company is located.

The GTU consisted of an anaerobic filter followed by a UV disinfection device. A $500 \mathrm{~L}$ tank was used for flow regulation prior to the anaerobic filter; another $500 \mathrm{~L}$ tank was used for storing treated greywater. The unit was constructed in order to work entirely by gravity to avoid pumping systems. Fig. 1 presents schematically the arrangement of the GTU.
The anaerobic filter is a fixed-bed biological reactor. The choice of such treatment system is justified by the high removals of organic matter and easy adaptation to different operation conditions.

The anaerobic filter was made of fiberglass and was $1.80 \mathrm{~m}$ high with a diameter of $1.00 \mathrm{~m}\left(1.41 \mathrm{~m}^{3}\right)$. The operation flow was maintained at $2.82 \mathrm{~m}^{3}$ day $^{-1}$. A grid was installed at $0.30 \mathrm{~m}$ from the bottom in order to distribute the flow inside the filter and avoid preferential flow paths. The filter support medium consisted of electrical conduits of diameter 1", cut into pieces of $4 \mathrm{~cm}$ each. This material was chosen for its low density and the higher specific surface when compared to crushed gravel.

In the UV disinfection system, the pipe for effluent runoff was $30 \mathrm{~cm}$ long and had an internal diameter of $8 \mathrm{~cm}$. The UV lamps worked with $36 \mathrm{~W}$. These characteristics provided a UV radiation intensity of $114 \mathrm{~mW} \mathrm{~cm}^{-2}$ applied to the liquid medium.

\subsection{Operation and monitoring}

The treatment system consisting of an anaerobic filter and UV disinfection was operated for six months, with weekly sampling campaigns. On sampling days, environmental variables such as $\mathrm{pH}$ and temperature were measured at the site, using Hach HQ40d portable meter. For the other variables, simple samples were collected prior and after the anaerobic filter. Were analyzed the following variables of water quality: biochemical oxygen demand (BOD) (5220B), chemical oxygen demand (COD) (5220D), total solids (TS) (2540B), total suspended solids (TSS) (2540D), turbidity (2130B), oils and grease (5520A), ammonia nitrogen $\left(\mathrm{N}-\mathrm{NH}_{4}^{+}\right)\left(4500-\mathrm{NH}_{3} \mathrm{C}\right)$ and nitrate $\left(\mathrm{N}-\mathrm{NO}_{3}^{-}\right)\left(4500-\mathrm{NO}_{3} \mathrm{E}\right)$. The analyses were performed as recommended by the Standard Methods for the Examination of Water and Wastewater (APHA, 2005), and the methods used for analysis of each variable are between parentheses. Moreover, after the UV disinfection device samples were collected for Escherichia coli (E. coli) $\left(\right.$ Colilert ${ }^{\circledR}$ ) analysis.

\subsection{Economic analysis}

The economic analysis was performed by using the Net Present Value (NPV) and the Payback period. The NPV comprises all expected expenses and revenues at a certain discount rate, presenting the return of the investment in a certain period. The payback is obtained when the NPV is equal to zero and considers many different factors, such as opportunity costs, discount rates and inflation during the analyzed period. These indexes are commonly used to evaluate different alternative water system options

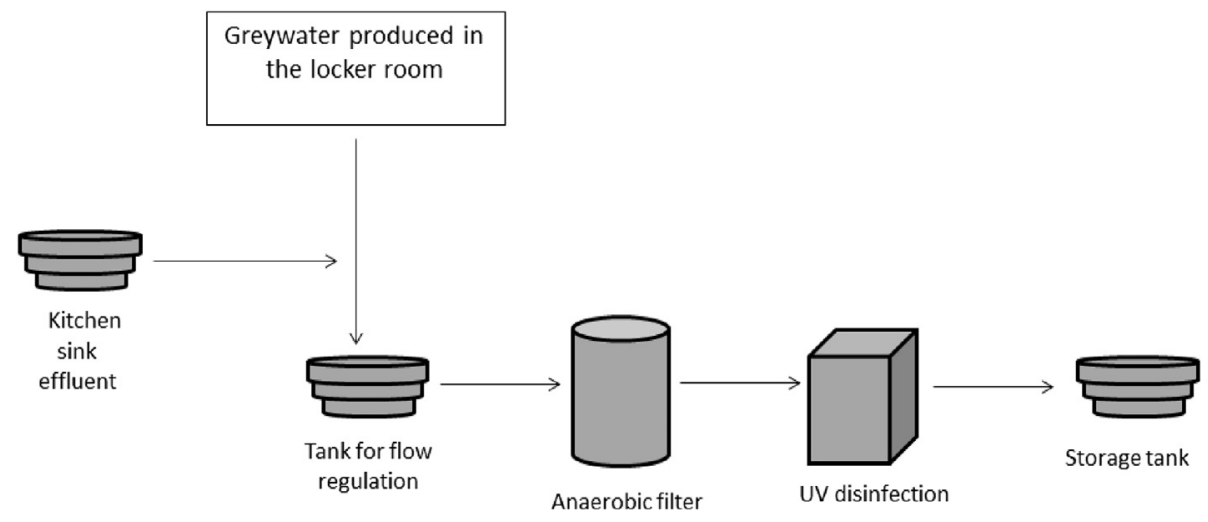

Fig. 1. Greywater treatment unit (GTU). 
(Swamee and Sharma, 2008; Farreny et al., 2011; Moreira Neto et al., 2012b).

The NPV calculation is shown in Equation (1):

$\mathrm{NPV}=-I+\sum_{t=0}^{n} \frac{B_{t}-C_{t}}{(1+i)^{t}}$

The payback period is obtained according to Equation (2):

$I=\sum_{t=0}^{n} \frac{B_{\mathrm{t}}-C_{\mathrm{t}}}{(1+i)^{\mathrm{t}}}$

where $I$ is the initial investment, $B_{\mathrm{t}}$ are the benefits and $C_{\mathrm{t}}$ are the costs in the period $\mathrm{t}$ and $i$ is the discount rate in both equations.

The payback is represented by $t$ and is calculated iteratively until the two sides of the equation are equal.

These indexes consider all the costs involving greywater treatment and reuse system construction, the operation and maintenance costs in an established period of time, as well as the financial and environmental benefits of the reduction of the potable water demand.

In this analysis a discount rate of $1 \%$ has been considered, provided that alternative water sources generate positive environmental and social benefits (Domènech and Saurí, 2011). Moreira Neto et al. (2012b) also selected this value for economic analysis of rainwater harvesting in airports. The authors stated that longterm water is likely to become more valuable and therefore, it would seem unwise to underestimate this value.

The analysis was performed by establishing a scenario for greywater reuse in TNIA, including the installation of a treatment system in each of the following airport buildings: Internal Revenue Service (IRS), Cargo Terminal (CT), Fire Section (FS), Airspace Control (AC), Fuel Area (FA), Equipment Shelter (ES), RA Group restaurant (RA) and the Infraero Maintenance Building (MB). Couto et al. (2013) evaluated the greywater production and the nonpotable water demand in each of these buildings. These results were used to estimate the implementation costs and the benefits obtained by the non-use of potable water.

For each system were considered, besides the anaerobic filter and UV disinfection device, a tank for raw greywater storage, a tank for flow regulation prior to the anaerobic filter, a tank for treated effluent distribution and two hydraulic pumps- one for the raw effluent and another for the treated. Implementation costs (fiberglass filter, tanks and pumps) were obtained from Caixa Econômica Federal, a bank in Brazil which finances basic sanitation projects such as water supply systems (CEF, 2014).

Operational and maintenance costs were related to energy consumption by pumps and by UV disinfection device, plus the salary of an employee responsible for maintenance the 8 systems. The cost of the energy consumed by hydraulic pumps was estimated considering the use of 368 Watts pumps, working $1 \mathrm{~h}$ per day during 30 days in the month. For the UV disinfection device, the energy cost was estimated considering 36 Watts lamps, 24 h per day during 30 days in the month. The price of electricity paid by INFRAERO to the local energy company was assumed to be US\$ $0.15 / \mathrm{kWh}$ (INFRAERO, personal communication). A cost of US\$ $814.50 /$ month with salary and charges of the employee was considered.

The financial saving derived from not using potable water was calculated through the production of greywater in the mentioned buildings (13,039 $\mathrm{m}^{3} /$ year) described by Couto et al. (2013) and the price of water provided by the local supply company (US\$ $2.53 \mathrm{~m}^{-3}$ ) (INFRAERO, personal communication).
An annual inflation rate of $6 \%$ - average value for the last years in Brazil - was assumed for the operation and maintenance costs and also for the benefits obtained for water savings. All costs were obtained in $\mathrm{R} \$$ (Brazilian Real) and converted to US dollars using the conversion rate on 09 July 2014 : US\$ $1=\mathrm{R} \$ 2.21$.

\section{Results}

\subsection{Efficiency evaluation of the treatment system}

During the operation of the anaerobic filter, the temperature ranged from 20 to $28^{\circ} \mathrm{C}$.

Table 2 presents the removal efficiencies and mean concentrations of organic matter, solids, oils and grease, ammonia nitrogen and nitrate for both untreated and treated effluent.

$\mathrm{pH}$ average values for raw and treated greywater were 7.6 and 7.7, respectively, with standard deviation of 0.31 and 0.27 . In anaerobic reactors, the maintenance of $\mathrm{pH}$ near 7.0 is essential for the good functioning of the system, i.e., the buffering capacity is necessary and also the stability of the microorganisms responsible for anaerobic digestion. More specifically, it is necessary to control the partial $\mathrm{H}_{2}$ pressure to guarantee the activity of methanogenic archaea in the filter medium.

Removal efficiencies were $73 \%$ for $\mathrm{BOD}_{5}$ and $71 \%$ for COD. Hernández-Leal et al. (2011) obtained similar results (70\% COD removal efficiency) when studying greywater biodegradability in anaerobic reactors. Elmitwalli and Otterpohl (2007) assessed greywater treatment using UASB reactors (Upflow Anaerobic Sludge Blanket) and obtained a removal efficiency of $64 \%$ for COD. Other studies that evaluated the use of anaerobic filters in the treatment of slaughterhouse effluent (Gannoun et al., 2009) and domestic sewage (Joung et al., 2009) presented an efficiency of 75\% for COD removal, which is coherent with the results obtained in this study.

The concentrations of both total and suspended solids allow us to infer about the high load of dissolved solids in the untreated greywater, which can be explained by the characteristics of the supply water in the TNIA. As aforementioned, the airport is supplied by groundwater with high levels of dissolved solids, since it is situated in a karstic region where interaction with soil facilitates its dissolution into the water. Total solids removal was low, with a mean value of $16 \%$.

For turbidity and suspended solids, the removal efficiencies were $88 \%$ and $77 \%$, respectively. These results allow us to infer that the low total solids removal was due to the high content of suspended solids removed, and thus dissolved solids concentrations were not significantly affected.

For all sampling campaigns, oils and grease were not found in treated greywater. The monitoring of such variables is important since high levels of such components can reduce treatment efficiency in anaerobic reactors by limiting the degradation of soluble substrate by the biomass (Jeganathan et al., 2006). However, the mean concentration of oils and grease in the untreated greywater

\section{Table 2}

Mean concentrations and standard deviation (between parenthesis) in greywater and in the effluent from the anaerobic filter.

\begin{tabular}{|c|c|c|c|}
\hline & Untreated effluent & Treated effluent & Removal efficiency \\
\hline $\mathrm{pH}$ & $7.6(0.31)$ & $7.7(0.27)$ & - \\
\hline $\mathrm{BOD}_{5}\left(\mathrm{mg} \mathrm{L}^{-1}\right)$ & $93(68)$ & $25(17)$ & $73 \%$ \\
\hline $\operatorname{COD}\left(\mathrm{mg} \mathrm{L}^{-1}\right)$ & $170(100)$ & $48(21)$ & $72 \%$ \\
\hline $\mathrm{TS}\left(\mathrm{mg} \mathrm{L}^{-1}\right)$ & 461 (119) & 385 (132) & $16 \%$ \\
\hline $\mathrm{TSS}\left(\mathrm{mg} \mathrm{L}^{-1}\right)$ & $76(37)$ & $17(11)$ & $77 \%$ \\
\hline Turbidity (NTU) & $40.4(27.1)$ & $4.8(2.8)$ & $88 \%$ \\
\hline $\mathrm{O} \& \mathrm{G}\left(\mathrm{mg} \mathrm{L}^{-1}\right)$ & $22.8(13.6)$ & $0.0(0.0)$ & $100 \%$ \\
\hline $\mathrm{N}-\mathrm{NH}_{4}^{+}\left(\mathrm{mg} \mathrm{L}^{-1}\right)$ & $36(16)$ & $47(11)$ & - \\
\hline $\mathrm{N}-\mathrm{NO}_{3}^{-}\left(\mathrm{mg} \mathrm{L}^{-1}\right)$ & $7.4(6.7)$ & $3.0(2.5)$ & $60 \%$ \\
\hline
\end{tabular}


was $22.8 \mathrm{mg} \mathrm{L}^{-1}$, which is lower than the value usually found in domestic sewage. According to Travis et al. (2008), such value can vary between 50 and $100 \mathrm{mg} \mathrm{L}^{-1}$. The low influent concentration may have been removed by the filter medium, without compromising the activity of the microorganisms in the reactor.

Table 2 also presents the mean concentrations of $\mathrm{N}-\mathrm{NH}_{4}^{+}$and $\mathrm{N}-\mathrm{NO}_{3}^{-}$. It can be observed an increase of ammonia nitrogen, which can be explained by the fact that in anaerobic reactors, ammonia is released through amino acid degradation, in the acidogenesis phase. Other studies have shown lower concentrations of ammonia nitrogen in greywater (Eriksson et al., 2002; Elmitwalli and Otterpohl, 2007; Li et al., 2009; Hernández-Leal et al., 2011); however, different from the present study, they did not consider the presence of urine in the shower effluent. The reduction in nitrate concentration may be a consequence of the denitrification process, which takes place predominantly in anoxic environments. Even though the norms and regulations for effluent reuse have not yet established limit values for the nitrogen forms, the monitoring of such variable gains importance when considering reuse for irrigation purposes. In this case, the effluent may serve not only as a source of water, but also of nitrogen for vegetal species. Couto et al. (2013) corroborate such information by saying that the most consuming activity which does not require potable water in the TNIA is landscape irrigation.

The UV disinfection presented total E. coli removal in $80 \%$ of the samples analyzed, and for the remaining $20 \%$, the concentrations of such organisms did not exceed $10^{0} \mathrm{MPN} / 100 \mathrm{ml}$. Friedler and GIlboa (2010) studied the use of UV radiation for greywater disinfection with reuse purposes (toilet flushing) and obtained results similar to those presented in this study, with $100 \%$ E. coli removal. The same authors state that health risks related to reuse of greywater properly disinfected by UV radiation are insignificant. Considering the microbiological quality provided by UV disinfection and the infecting doses of pathogenic organisms, a person would need to be in contact with great volumes of such effluent for a long period of time in order for it to represent a high health risk.

\subsection{Economic analysis}

The implementation cost of greywater treatment system in the TNIA buildings was US $\$ 22,905.75$, with a payback period of 5 years. Moreover, in a 10 years period, the NPV for the considered inflation and discount rate was US\$ 1048.00 .

The period of time required to return the investment in the greywater treatment and reuse system in the TNIA was relatively short, with reduction perspectives considering the cost of a cubic meter of water paid by TNIA, which is relatively low compared to other places. These values were obtained for a specific and well-defined scenario, proving through a widely used numerical method the economic viability of greywater reuse in airports by a simple technology. However, there are other scenarios that can be as, or more viable - both financially and environmentally - than the one described.

It is important to highlight the possibility of integration between measures related to water conservation practices and to renewable energy sources. Airport environments have large rooftop areas, which can collect big volumes of rainwater, thereby meeting a greater fraction of non-potable water demand (Moreira Neto et al., 2012b). Furthermore, the use of solar energy for pumps functioning and for UV disinfection device may represent a reduction in operating costs.

\section{Discussion}

Airports are environments with great potential for greywater reuse given their significant water consumption, mostly for non- potable activities, to maintain their infrastructure (Couto et al., 2013). Especially in the context of expansion of airport capacity, these environments face great environmental challenges and demand studies aimed at developing technologies to conserve the environmental resources (Asinjo, 2011). In Brazil, such studies have an even greater urgency because most airports are undergoing renovations and are expanding to accommodate two important international sporting events, the FIFA World Cup in 2014 and the Olympic Games in 2016 (Carvalho et al., 2013).

Several factors influence water consumption in airports, and consequently encourage the adoption of policies and practices related to its rational use. Even though the index liters/passenger is widely used, other factors such as the airport type (international or domestic flights), number of flights and cargo transportation, among others, can significantly interfere in water consumption (Carvalho et al., 2013).

The present study proved the possibility of treating greywater produced in airports using simple and low-cost technologies, with a period of time required to return the investment of 5 years, which are also easy to replicate, in agreement with the concept of sourceseparated effluent.

The comparison of the results with the norms presented in Table 1 shows that the anaerobic filter has fully met the less restrictive regulations, and the most restrictive ones were satisfied for some variables. The mean TSS concentration has met all standards presented in Table 1. For turbidity, the mean value obtained was not sufficient to meet the strictest requirements established by USEPA (2004). For BOD, the mean value obtained was satisfactory, according to USEPA (2004) for use in construction (soil compaction, dust control, washing aggregate, making concrete) and restricted access area irrigation (sod farms, areas where public access is prohibited). Removal of organic matter and solids by the anaerobic filter may have been favored by the high specific area and porosity of the support medium. The corrugated conduit allows the establishment of biofilm both internally and externally, increasing the effluent contact with the anaerobic biomass.

Hernández-Leal et al. (2011) reinforce the applicability of anaerobic processes for greywater treatment due to the reduced nutrient concentration, which can limit the efficiency of aerobic processes. This condition was not confirmed in the present study, probably due the presence of urine in the effluent from the showers, which increased the $\mathrm{N}-\mathrm{NH}_{4}^{+}$concentration in greywater, although several studies have reported low nutrient concentration in such type of effluent (Al-Jayyousi, 2003; Lamine et al., 2007; Hernández-Leal et al., 2007).

Including a disinfection step in an effluent reuse system is justified by the reduction of health risks due to pathogenic organisms. Friedler and Gllboa (2010) state that the UV disinfection is especially adequate for small treatment units and presents some advantages such as the non-use of chemical products, the effective removal of a series of pathogens, some of which are resistant to chlorine, the non-production of byproducts and the safer operation. In the case study, the UV disinfection was efficient with respect to microorganisms inactivation. All samples presented maximum E. coli concentrations in the order of $10^{0} \mathrm{NMP} / 100 \mathrm{ml}$, satisfying all requirements present in Table 1 , for all uses. Another commonly used alternative is chlorination, which can also contribute to the maintenance of residual chlorine. Only WHO (2006) does not present limit values for residual chlorine, which is necessary to avoid the proliferation of microorganisms in pipes and reservoirs. Thus it is possible to infer that the UV disinfection has more applicability when greywater is intended to be used for irrigation.

In the TNIA, greywater production is sufficient to meet the nonpotable water demand, and in qualitative terms, the effluent has similar characteristics to those presented in the literature for 
greywater produced in households, which allows us to say that both quantitative and qualitative aspects are not limitations to its use (Couto et al., 2013). However, it is important to highlight the necessity of integrating solutions related to alternative sources and demand reduction, according to the characteristics of each airport. Greywater is one of the alternative sources that can be considered to compose this group of practices. As an example we mention the Hong Kong International Airport, which has a water distribution system that uses potable water, seawater and greywater for sinks/ lavatories and washing of aircrafts, and reduced consumption in up to $50 \%$ (Grant et al., 2012).

The major challenges in greywater treatment in order to meet all quality requirements are the fact that the quality of such effluent varies according to source, geographical location, demographics and level of occupancy, (Al-Jayyousi, 2003) and the volume varies during the day. Thus, the choice of a greywater treatment technology must satisfy some criteria and respect the different characteristics of each airport. This choice should be made based on what activities greywater will be used for, among other issues (Ghaitidak and Yadav, 2013). The technology presented in the case study is low-cost and easily operated, and mostly indicated for small and mid-size airports, or large airports with decentralized treatment. This does not limit the applicability of the system to developing countries only. In developed countries, the infrastructure related to water very often needs to be modified in order to satisfy a high quality life style and, at the same time, reduce its energy consumption and negative environmental impacts (Grant et al., 2012). The most common technologies currently used for greywater treatment in airports mentioned in Section 3 are more sophisticated and expensive. In fact, they were designed for decentralized treatment stations in large airports, with water consumption similar to that of small and mid-size cities.

Finally, considering the systems presented for greywater treatment in airports and other situations, we observe that using only one technology will hardly be enough to satisfy reuse standards. Thus, we point out the necessity to combine technologies in order to enable greywater reuse under the more restrictive requirements (Ghaitidak and Yadav, 2013). We also highlight the need to evaluate specific criteria and characteristics for each airport, namely the number of passengers, category, location, number of permanent employees, activities where treated greywater can be used, among others, for the adoption of the most suitable combination.

\section{Conclusions}

Within a context of airport expansion and given the urgent need of adopting sustainable practices at all levels of the society, greywater represents an alternative source with potential for use in activities which do not require potable water.

The source-separated effluent can facilitate treatment and reuse: it enables the use of low-energy consumption and easy operation technologies. The treatment system consisted of an anaerobic filter and UV disinfection met international reuse recommendations for non-potable activities. It also presented a payback period of five years for the proposed scenario, being strongly indicated for small or mid-size airports or decentralized treatment in large airports. This conclusion is important since that greywater reuse should be implemented respecting the peculiarities of each airport.

We thus conclude that it is possible to treat greywater produced in airport environments using simple technologies which are easily replicable, inexpensive and that satisfy international reuse recommendations for non-potable activities. Thus greywater reuse is an important alternative for saving water in airport environments.

\section{Acknowledgments}

The authors acknowledge the financial assistance provided by the Research and Projects Financing, FINEP and the Foundation for Research Support of Minas Gerais, FAPEMIG.

\section{References}

ABNT, NBR 13969, 1997. Tanques sépticos - unidades de tratamento complementar e disposição final dos efluentes líquidos - projeto, construção e operação (Septic Tanks - complementary treatment units and final disposal of liquid effluents - project, construction and operation). Brazilian Association of Technical Standards, Rio de Janeiro (in Portuguese).

ADP Aéroports de Paris, 2010. Corporate Social Responsibility Report. Available at: http://services.aeroportsdeparis.fr/ADP.DownLoadManager/getFile.aspx? ideFile $=64$ (accessed 22.10.13.).

ADR Aeroporti di Roma, 2009. Environmental Report. Available at: http://www.adr. it/c/document library/get file?uuid=e60b5298-f5ac-415c-80aa62abfe6c4b46\&groupId=17615 (accessed 21.10.13.).

Al-Jayyousi, O.R., 2003. Greywater reuse: towards sustainable water management. Desalination 156, 181-192.

APHA, 2005. Standard Methods for the Examination of Water and Wastewater, 21st ed. American Public Health Association, American Water Works Asso-ciation, Water Environmental Federation, Washington.

Asinjo, Dora-Anne, 2011. Environmental Management at Sustainable Airport Models. Research Papers. Paper 257. Available at: http://opensiuc.lib.siu.edu/gs_ rp/257 (accessed 21.10.13.).

Boeing Management Company, 2010. Current Market Outlook 2010-2029. Seattle, WA.

Calijuri, M.L., Couto, E.A., Santiago, A.F., Camargo, R.A., Silva, M.D.F.M., 2012. Evaluation of the influence of natural and anthropogenic processes on water quality in karstic region. Water Air Soil Pollut. 223 (5), 2157-2168.

Carvalho, I.C., Calijuri, M.L., Assemany, P.P., Silva, M.D.F.M., Moreira Neto, R.F., Santiago, A.F., Souza, M.H.B., 2013. Sustainable airport environments: a review of water conservation practices in airports. Resour. Conserv. Recycl. 74, 27-36.

CEF Caixa Econômica Federal, 2014. Research on Basic Sanitation Projects Construction Costs. Available at: https://www.webp.caixa.gov.br/casa/sinapi/ interno.asp (accessed 30.06.14.).

Couto, E.A., Calijuri, M.L., Assemany, P.P., Santiago, A.F., Carvalho, I.C., 2013. Greywater production in airports: qualitative and quantitative assessment. Resour. Conserv. Recycl. 77, 44-51.

DCA Dubai Department of Civil Aviation, 2004. Public Environment Report. Available at: http://www.aerohabitat.eu/uploads/media/12-01-2009 - DubaiAirport - Public Environmental Report 2003-04.pdf (accessed 22.10.13.).

DOA Atlanta Department of Civil Aviation - Hartsfield-Jackson Atlanta International Airport, 2011. Sustainable Management Plan. Available at: http://www. atlanta-airport.com/docs/Airport/Sustainability/Sustainable\%20Management\% 20Plan.pdf (accessed 24.10.13.).

Domènech, L., Saurí, D., 2010. Socio-technical transitions in water scarcity contexts: public acceptance of greywater reuse technologies in the Metropolitan Area of Barcelona. Resour. Conserv. Recycl. 55, 53-62.

Domènech, L., Saurí, D., 2011. A comparative appraisal of the use of rooftop rainwater in single and multi-family buildings of the metropolitan area of Barcelona (Spain): social experience, drink water savings and economic costs. J. Clean. Prod. 19, 598-608.

Elmitwalli, T.A., Otterpohl, R., 2007. Anaerobic biodegradability and treatment of grey water in upflow anaerobic sludge blanket (UASB) reactor. Water Res. 41, 1379-1387.

Environment Agency, 2011. Greywater for Domestic Users: an Information Guide. Available at: http://www.environment-agency.gov.uk (accessed 02.11.13.).

Eriksson, E., Auffarh, K., Henze, M., Ledin, A., 2002. Characteristics of grey wasterwater. Urban Water 4, 85-104.

Farreny, R., Gabarrell, X., Rieradevall, J., 2011. Cost-efficiency of rainwater harvesting strategies in dense Mediterranean neighbourhoods. Resour. Conserv. Recycl. 55, 686-694.

Friedler, E., GIlboa, Y., 2010. Performance of UV disinfection and the microbial quality of greywater effluent along a reuse system for toilet flushing. Sci. Total Environ. 408, 2109-2117.

Gannoun, H., Bouallagui, H., Okbi, A., Hamdi, M., 2009. Mesophilic and thermophilic anaerobic digestion of biologically pretreated abattoir wastewaters in an upflow anaerobic filter. J. Hazard. Mater. 170, 263-271.

Ghaitidak, D.M., Yadav, K.D., 2013. Characteristics and treatment of greywater - a review. Environ. Sci. Pollut. Res. 0, 2795-2809.

Gilboa, Y., Friedler, E., 2008. UV disinfection of RBC-treated light greywater effluent: kinetics, survival and regrowth of selected microorganisms. Water Res. 42, 1043-1050.

Godfrey, S., Labhasetwar, P., Wate, S., 2009. Greywater reuse in residential schools in Madhya Pradesh, India-A case study of cost-benefit analysis. Resour. Conserv. Recycl. 53, 287-293.

Grant, S.B., Saphores, J.D., Feldman, D.L., Hamilton, A.J., Fletcher, T.D., Cook, P.L.M., Stewardson, M., Sanders, B.F., Levin, L.A., Ambrose, R.F., Deletic, A., Brown, R., Jiang, S.C., Rosso, D., Cooper, W.J., Marusic, J., 2012. Taking the "Waste" out of 
"Wastewater" for human water security and ecosystem sustainability. Science 337, 681-686.

Gross, A., Shmueli, O., Ronen, Z., Raveh, E., 2007. Recycled vertical flow constructed wetland (RVFCW) - a novel method of recycling greywater for irrigation in small communities. Chemosphere 66 (5), 916-923.

Hernández Leal, L., Temmink, H., Zeeman, G., Buinman, C.J.N., 2010. Bioflocculation of grey water for improved energy recovery within decentralized sanitation concepts. Bioresour. Technol. 101, 9065-9070.

Hernández Leal, L., Temmink, H., Zeeman, G., Buisman, C.J.N., 2011. Characterization and anaerobic biodegradability of grey water. Desalination 270, 111-115.

Hernández Leal, L., Zeeman, G., Temmink, H., Buisman, C., 2007. Characterisation and biological treatment of greywater. Water Sci. Technol. 56, 193-200.

HKIA Hong Kong International Airport, 2011. Plant the Future-annual Report 2010/ 2011. Available at: http://www.hongkongairport.com/eng/pdf/media/ publication/report/10 11/e full.pdf (accessed 03.11.13.).

INFRAERO, 2013. Empresa Brasileira de Infraestrutura Aeroportuária. Available at: http://www.infraero.gov.br/index.php/br/imprensa/noticias/5597-310-aeroportode-confins-inaugura-mais-uma-ponte-de-embarque.html (accessed 26.10.13.).

Jeganathan, J., Bassi, A., Nakhla, G., 2006. Pre-treatment of high oil and grease pet food industrial wastewaters using immobilized lipase hydrolyzation. J. Hazard. Mater. 137, 121-128.

Joung, J.Y., Lee, H.W., Choi, H., Lee, M.W., Park, J.M., 2009. Influences of organic loading disturbances on the performance of anaerobic filter process to treat purified terephthalic acid wastewater. Bioresour. Technol. 100, 2457-2461.

Lamine, M., Bousselmi, L., Ghrabi, A., 2007. Biological treatment of grey water using sequencing batch reactor. Desalination 215, 127-132.

Larsen, T.A., Alder, A.C., Eggen, R.I.L., Maurer, M., Lienert, J., 2009. Source Separation: Will We See a paradigm shift in wastewater handling? Environ. Sci. Technol. 43, $6121-6125$

Lesjean, B., Gnirss, R., 2006. Grey water treatment with a membrane bioreactor operated at low SRT and low HRT. Desalination 199, 432-434.

LHR London Heathrow Airport, 2010. Sustainability Performance Summary. Available at: http://www.heathrowairport.com/static/Heathrow/Downloads/PDF/ 2010-sustainability-performance-summary.pdf (accessed 25.10.13.).

Li, F., Wichmann, K., Otterpohl, R., 2009. Review of the technological approaches for grey water treatment and reuses. Sci. Total Environ. 407, 3439-3449.

Li, Z., Gulyas, H., Jahn, M., Gajurel, D.R., Otterpohl, R., 2003. Greywater treatment by constructed wetland in combination with $\mathrm{TiO}_{2}$-based photocatalytic oxidation for suburban and rural areas without sewer system. Water Sci. Technol. 48 (11), 101-106.

Liu, S., Butler, D., Memon, F.A., Makropoulos, C., Avery, L., Jefferson, B., 2010. Impacts of residence time during storage on potential of water saving for grey water recycling system. Water Res. 44, 267-277.
MAG Manchester Airport Group, 2007. Environmental Plan (Part of the Manchester Airport Master Plan to 2030). Available at: http://www.manchesterairport.co. uk/manweb.nsf/AttachmentsByTitle/EnvironmentPlan/\$FILE/Environplan.pdf (accessed 24.10.13.).

March, J.G., Gual, M., Orozco, F., 2004. Experiences on greywater re-use for toilet flushing in a hotel (Mallorca Island, Spain). Desalination 164 (3), 241-247.

MHC, 2010. Canadian Guidelines for Domestic Reclaimed Water for Use in Toilet and Urinal Flushing. Minister of Health Canada, Ottawa, Ontario.

Moreira Neto, R.F., Carvalho, I.C., Calijuri, M.L., Santiago, A.F., 2012b. Rainwater use in airports: a case study in Brazil. Resour. Conserv. Recycl. 68, 36-43.

Moreira Neto, R.F., Calijuri, M.L., Carvalho, I.C., Santiago, A.F., 2012a. Rainwater treatment in airports using slow sand filtration followed by chlorination: efficiency and costs. Resour. Conserv. Recycl. 65, 124-129.

Muthukumaran, S., Baskaran, K., Sexton, N., 2011. Quantification of potable water savings by residential water conservation and reuse. Resour. Conserv. Recycl. 55, 945-952.

Nelson, K.L., Murray, A., 2008. Sanitation for unserved populations: technologies implementation challenges and opportunities. Annu. Rev. Environ. Resour. 33 $119-151$.

NIAC Narita International Airport Corporation, 2011. Narita Airport Environment Report. Available at: http://www.naa.jp/en/environment/pdf2011/ kankyoreport2011.pdf (accessed 18.10.13.).

NSW, 2002. Greywater Reuse in Sewered Single Domestic Premises. NSW Health, Sidney.

Pidou, M., Avery, L., Stenphenson, T., Jeffrey, P., Parsons, S.A., Liu, S., Memon, F.A., Jefferson, B., 2008. Chemical solutions for greywater recycling. Chemosphere 71 147-155.

Pinto, U., Maheswari, B.L., Grewal, H.S., 2010. Effects of greywater irrigation on plant growth, water use and soil properties. Resour. Conserv. Recycl. 54, 429-435.

Swamee, P.K., Sharma, A.K., 2008. Design of Water Supply Pipe Networks. John Wiley, New York.

Travis, M.J., Weisbrod, N., Gross, A., 2008. Accumulation of oil and grease in soils irrigated with greywater and their potential role in soil water repellency. Sci. Total Environ. 394, 68-74.

USEPA - United States Environmental Protection Agency, 2004. Manual: Guidelines for Water Reuse, Washington. DC.

WHO - World Health Organization, 2006. Guidelines for the Safe Use of Wastewater, Excreta and Greywater. In: Wastewater and Excreta Use in Agriculture, vol. 2. Geneva.

Winward, G.P., Avery, L.M., Stephenson, T., Jefferson, B., 2008. Chlorine disinfection of grey water for reuse: effect of organics and particles. Water Res. 42, 483-491. 